\title{
ANALISIS PENERAPAN PSAK NO.30 (REVISI 2011) ATAS AKUNTANSI LEASING PADA PT. FEDERAL INTERNATIONAL FINANCE (FIF) CABANG MANADO
}

\author{
Oleh: \\ Yusni Husain \\ Heince Wokas \\ Program Pendidikan Profesi Akuntansi \\ Fakultas Ekonomi dan Bisnis \\ Universitas Sam Ratulangi Manado \\ Email: yusnihusain@gmail.com
}

\begin{abstract}
PT. Federal International Finance (FIF) is a credit financing institution engaged in the business of credit financing. PT. FIF provides credit services to customers with expected profits derived from loan interest, so PT. FIF has a good amount of lease receivables. Therefore, any application of lease accounting in accordance with SFAS 30 (Revised 2011) on lease accounting. This study aims to determine the application of lease accounting PT. FIF. The research method used comparative descriptive method. The results showed the application of PT. FIF has been in accordance with the applicable standards. In recognition of finance lease PT. FIF has been in accordance with the applicable accounting standards for finance leases are recognized at fair value, net of transaction costs that occur. PT. FIF use leasing capital lease accounting model, can be seen from the provisions of the lease on the company's letter, stating their option rights for the lease upon expiration of the lease, where the provisions of this falls in the existing criteria on capital lease. In the final days of capital lease rental payments, the option to lease the vehicle ownership. PT. FIF use leasing capital lease accounting model by the method of direct financing leases or direct financing method.
\end{abstract}

\section{Keywords: Leasing, Application, Leasing Accounting}

\section{PENDAHULUAN}

\section{Latar Belakang}

Pembangunan nasional merupakan upaya pembangunan yang berkesinambungan dalam rangka mewujudkan masyarakat yang adil dan makmur berdasarkan Pancasila dan Undang-undang Dasar 1945. Dalam menghadapi perkembangan perekonomian nasional yang senantiasa bergerak cepat, kompetitif, dan terintegrasi dengan tantangan yang semakin kompleks serta sistem keuangan yang semakin maju, diperlukan penyesuaian kebijakan di bidang ekonomi, termasuk lembaga pembiayaan.

Perluasan usaha yang dilakukan oleh produsen membutuhkan dana yang relatif besar. Untuk menunjangnya, saat ini banyak berkembang perusahaan pembiayaan di Indonesia. Leasing atau sewa guna usaha merupakan alternatif pembiayaan yang dibutuhkan para produsen, disamping cara-cara konvensional yang lazim dilakukan melalui perbankan.

PT. Federal Internasional Finance (FIF) merupakan lembaga pembiayaan kredit yang bergerak dalam usaha pembiayaan kredit. PT. Federal Internasional Finance (FIF) memberikan pelayanan kredit kepada nasabah dengan mengharapkan laba yang diperoleh dari bunga kredit tersebut. PT. Federal Internasional Finance (FIF) cabang Manado menjadi objek dalam penelitian ini yang mempunyai berbagai produk sehingga sumber penerimaan 
kas perusahaan menjadi beraneka ragam, maka perlakuan akuntansi leasing telah menjadi masalah rumit dan kompleks. Struktur dan proses penerapan akuntansi sewa guna usaha haruslah dipahami secara baik. Manajemen membutuhkan informasi yang akurat dan cukup untuk memudahkan pengelolaan perusahaan, untuk mempertahankan eksistensinya dan untuk mencapai tujuan perusahaan. Oleh karena itu, sewa guna usaha dalam perusahaan pembiayaan harus diterapkan sesuai dengan standar akuntansi yang berlaku.

Permasalahan pengakuan dan pengukuran serta pengungkapan saling terkait satu sama lain. Permasalahan ini perlu diteliti pada PT. Federal International Finance dengan melakukan penyesuaian dengan PSAK No.30. Apabila penerapan akuntansi sewa guna usaha PT. FIF tidak sesuai dengan standar akuntansi maka hal ini dapat mengakibatkan informasi yang disajikan dalam laporan posisi keuangan tidak tepat dan dapat menyebabkan kesalahan dalam pengambilan keputusan oleh pihak manajemen perusahaan sehingga penting sekali dalam proses pengakuan, pengukuran serta pengungkapan menggunakan suatu standar sebagai acuan yaitu Standar Akuntansi Keuangan (SAK), khususnya PSAK No.30. Standar yang dikeluarkan oleh Ikatan Akuntan Indonesia (IAI) merupakan suatu pedoman dalam penyusunan laporan keuangan untuk tujuan pelaporan bagi pengguna laporan tersebut.

\section{TINJAUAN PUSTAKA Konsep Akuntansi}

Akuntansi sering diartikan sebagai bahasa bisnis (the language of business) atau lebih tepat sebagai bahasa dari keputusan keuangan. Semakin kita menguasai bahasa ini akan semakin baik pula kita menangani berbagai aspek keuangan dalam kehidupan ini. Akuntansi adalah suatu sistem informasi yang mengukur aktivitas-aktivitas bisnis, yang selanjutnya memproses informasi tersebut dalam bentuk laporan keuangan dan mengomunikasikannya kepada para pengambil keputusan (Santoso 2010:1).

\section{Akuntansi Keuangan}

Akuntansi keuangan (financial accounting) merupakan proses yang berpuncak pada penyiapan laporan keuangan perusahaan secara menyeluruh untuk digunakan oleh pihak internal dan eksternal perusahaan dalam rangka pengambilan keputusan (Santoso, 2010:9). Akuntansi keuangan menghasilkan informasi keuangan tentang sebuah entitas. Informasi keuangan yang dihasilkan adalah laporan keuangan (Martani, 2012:8).

\section{Sewa Guna Usaha}

Sewa guna usaha adalah perjanjian antara lessor (pemilik aset) dengan lessee untuk menggunakan suatu aset sewaan selama periode yang disepakati (Prihadi 2011:241). Perjanjian sebagai suatu peristiwa dimana seseorang berjanji kepada orang lain atau dimana dua orang itu saling berjanji untuk melaksanakan sesuatu hal (Izati, 2014).

Sewa diasumsikan untuk menggantikan utang, meskipun rasio substitusi tidak disepakati, leasing benar-benar dapat meningkatkan kapasitas utang perusahaan karena leasing dan pinjaman dapat saling melengkapi dalam struktur modal optimal perusahaan (Erickson \& Trevino, 2010).

Secara akuntansi, sewa dapat dibagi menjadi dua (Prihadi, 2011:243), yaitu sebagai berikut.

1. Sewa operasi (operating lease)

2. Sewa pembiayaan (finance lease)

\section{Standar Akuntansi Keuangan (SAK)}


Standar Akuntansi Keuangan (SAK) digunakan untuk entitas yang memiliki akuntabilitas publik yaitu entitas terdaftar atau dalam proses pendaftaran di pasar modal (yang menggunakan dana masyarakat seperti asuransi, perbankan, dan dana pensiun) (Martani, 2012:15). Standar ini mengadopsi IFRS melalui IAI, telah menetapkan untuk melakuan adopsi penuh IFRS mulai tahun 2012

Pernyataan Standar Akuntansi Keuangan berisikan pedoman untuk penyusunan laporan keuangan, pengaturan transaksi atau kejadian, dan komponen tertentu dalam laporan keuangan. Pengaturan terkait komponen laporan keuangan secara umum berisikan definisi, pengakuan, pengukuran, penyajian, dan pengungkapan.

\section{PSAK No 30 Tahun 2011 tentang Sewa}

Sewa adalah suatu perjanjian dimana lessor memberikan kepada lessee hak untuk menggunakan suatu aset selama periode waktu yang disepakati. Sebagai imbalannya, lessee melakukan pembayaran atau serangkaian pembayaran kepada lessor. Sewa pembiayaan adalah sewa yang mengalihkan secara substansial seluruh risiko dan manfaat yang terkait dengan kepemilikan suatu aset. Hak milik pada akhirnya dapat dialihkan, dapat juga tidak dialihkan (PSAK No 30 Tahun 2011).

Pengakuan awal: IAI ( 2012:30.35) dalam sewa pembiayaan, lessor mengakui aset berupa piutang sewa pembiayaan dilaporan posisi keuangan sebesar jumlah yang sama dengan investasi sewa neto tersebut. Pengukuran setelah pengakuan: IAI (2012:30.38) pengakuan penghasilan pembiayaan didasarkan pada suatu pola yang mencerminkan suatu tingkat pengembalian periodik yang konstan atas investasi bersih lessor dalam sewa pembiayaan.

Perlakuan akuntansi untuk sewa pembiayaan berdasarkan PSAK (IAI, 2012:30.21) adalah pembayaran sewa minimum harus dipisahkan antara bagian yang merupakan beban keuangan dan bagian yang merupakan pelunasan kewajiban. Beban keuangan harus dialokasikan ke setiap periode selama masa sewa sedemikian rupa sehingga menghasilkan suatu tingkat suku bunga periodik yang konstan atas saldo kewajiban.

Pelaporan akuntansi capital lease oleh penyewa guna usaha menurut PSAK No. 30 (Revisi 2011) adalah sebagai berikut.

1. Aktiva yang disewa guna usahakan dilaporkan sebagai bagian aktiva tetap dalam kelompok tersendiri. Kewajiban sewa guna usaha yang bersangkutan harus disajikan terpisah dari kewajiban lainnya.

2. Pengungkapan yang layak harus dicantumkan dalam catatan atas laporan keuangan mengenai hal-hal sebagai berikut :

a. Jumlah pembayaran sewa guna usahakan yang paling tidak untuk dua tahun berikutnya.

b. Penyusutan aktiva yang disewa guna usahakan yang dibebankan dalam tahun berjalan.

c. Jaminan yang diberikan sehubungan dengan transaksi sewa guna usaha.

d. Keuntungan atau kerugian yang ditangguhkan beserta amortisasinya sehubungan dengan transaksi penjualan dan penyewaan kembali (sale and leaseback).

e. Ikatan-ikatan penting yang dipersyaratkan dalam perjanjian sewa guna usaha.

Pelaporan dan Pengungkapan transaksi operating lease menurut PSAK No.30 bahwa pengungkapan yang layak harus dicantumkan atas laporan keuangan mengenai: 
1. Jumlah pembayaran sewa guna selama tahun berjalan yang dibebankan sebagai biaya sewa.

2. Jumlah pembayaran sewa guna usaha yang harus dilakukan paling tidak 2 tahun berikutnya.

3. Jaminan yang diberikan sehubungan dengan transaksi sewa guna usaha.

4. Keuntungan atau kerugian yang ditangguhkan beserta amortisasinya sehubungan dengan transaksi sale and leaseback.

5. Ikatan-ikatan penting yang dipersyaratkan dalam perjanjian sewa guna usaha (major covenants).

Penelitian Terdahulu

Tabel 1. Penelitian Terdahulu

\begin{tabular}{|c|c|c|c|c|c|c|}
\hline No & $\begin{array}{c}\text { Nama } \\
\text { Peneliti/ } \\
\text { Tahun }\end{array}$ & Judul & $\begin{array}{c}\text { Metode } \\
\text { Penelitia } \\
\text { n }\end{array}$ & Hasil Penelitian & Persamaan & Perbedaan \\
\hline 1. & $\begin{array}{l}\text { Rina \& } \\
\text { Hamdani } \\
(2012)\end{array}$ & $\begin{array}{l}\text { Analisis } \\
\text { Akuntansi } \\
\text { Leasing pada } \\
\text { PT. Puri } \\
\text { Green } \\
\text { Resources } \\
\text { Pekanbaru }\end{array}$ & $\begin{array}{l}\text { Kualitatif } \\
\text { deskriptif }\end{array}$ & $\begin{array}{lr}\text { Dalam } & \text { melakukan } \\
\text { pencatatan } & \text { terhadap } \\
\text { aktiva yang } & \text { dilease } \\
\text { PT. Puri } & \text { Green } \\
\text { Resources } & \\
\text { menggunakan } & \text { metode } \\
\text { operating } & \text { lease, } \\
\text { padahal } & \text { dalam } \\
\text { ketentuan kontraknya } \\
\text { perusahaan tersebut } \\
\begin{array}{lr}\text { tergolong } \\
\text { lease. }\end{array} & \text { capital } \\
\end{array}$ & $\begin{array}{l}\text { Menganalisis } \\
\text { tentang } \\
\text { akuntansi } \\
\text { leasing. }\end{array}$ & $\begin{array}{l}\text { Objek penelitian } \\
\text { dengan penelitian } \\
\text { ini berbeda } \\
\text { dengan penulis. }\end{array}$ \\
\hline 2. & $\begin{array}{l}\text { Kombaitan } \\
\text { (2012) }\end{array}$ & $\begin{array}{l}\text { Penerapan } \\
\text { PSAK No } 30 \\
\text { Tentang } \\
\text { perlakuan } \\
\text { Akuntansi } \\
\text { Sewa Aktiva } \\
\text { tetap pada } \\
\text { PD. Bangun } \\
\text { Bitung }\end{array}$ & $\begin{array}{l}\text { Kualitatif } \\
\text { deskriptif }\end{array}$ & $\begin{array}{l}\text { Perlakuan akuntansi } \\
\text { yang diterapkan PD. } \\
\text { Bangun Bitung belum } \\
\text { secara keseluruhan } \\
\text { menerapkan perlakuan } \\
\text { akuntansi sewa aktiva } \\
\text { tetap menurut PSAK } \\
\text { No. } 30 \text {. }\end{array}$ & $\begin{array}{l}\text { Menganalisis } \\
\text { dengan PSAK } \\
\text { No. } 30\end{array}$ & $\begin{array}{ll}\text { Peneliti } & \\
\text { sebelumnya } \\
\text { meneliti tentang } \\
\text { perlakukan } \\
\text { akuntansi sewa } \\
\text { aktiva tetap } \\
\text { sedangkan } & \\
\text { penulis } & \\
\text { akuntanasi } & \\
\text { leasing. } & \\
\end{array}$ \\
\hline 3. & $\begin{array}{l}\text { Sparta } \\
\text { Safitri } \\
(2012)\end{array}$ & $\begin{array}{l}\text { Analisis } \\
\text { Penerapan } \\
\text { PSAK No } 30 \\
\text { (Revisi } \\
\text { 2007) } \\
\text { Tentang } \\
\text { Sewa Guna } \\
\text { Usaha pada } \\
\text { PT X } \\
\end{array}$ & $\begin{array}{l}\text { Kualitatif } \\
\text { deskriptif }\end{array}$ & $\begin{array}{lr}\text { Perlakuan } & \text { akuntansi } \\
\text { leasing yang dilakukan } \\
\text { oleh PT X belum } \\
\text { sesuai } & \text { dengan } \\
\text { ketentuan } & \text { PSAK } \\
\text { No.30 (Revisi 2007). }\end{array}$ & $\begin{array}{l}\text { Menganalisis } \\
\text { tentang } \\
\text { akuntansi } \\
\text { leasing }\end{array}$ & $\begin{array}{l}\text { Objek penelitian } \\
\text { dengan penelitian } \\
\text { ini berbeda. } \\
\text { Penelitian } \\
\text { sebelumnya } \\
\text { menggunakan } \\
\text { PSAK No.30 } \\
\text { (Revisi 2007) }\end{array}$ \\
\hline
\end{tabular}




\begin{tabular}{|c|c|c|c|c|c|c|}
\hline 4. & $\begin{array}{l}\text { Irene } \\
(2013)\end{array}$ & $\begin{array}{l}\text { Penerapan } \\
\text { Akuntansi } \\
\text { Piutang } \\
\text { Leasing } \\
\text { untuk } \\
\text { Perencanaan } \\
\text { dan } \\
\text { Pengendalian } \\
\text { pada PT. } \\
\text { Suzuki Finance } \\
\text { Indonesia } \\
\text { Manado }\end{array}$ & $\begin{array}{l}\text { Kualitatif } \\
\text { deskriptif }\end{array}$ & $\begin{array}{l}\text { Penerapan akuntansi } \\
\text { pada PT. SFI Manado } \\
\text { menggunakan model } \\
\text { akuntansi leasing } \\
\text { capital lease dengan } \\
\text { model direct financing } \\
\text { lease. }\end{array}$ & $\begin{array}{l}\text { Menganalisis } \\
\text { tentang } \\
\text { akuntansi } \\
\text { leasing }\end{array}$ & $\begin{array}{l}\text { Objek penelitian } \\
\text { dengan penelitian } \\
\text { ini berbeda }\end{array}$ \\
\hline
\end{tabular}

Sumber: Data Olahan Tahun 2015

\section{METODE PENELITIAN}

Jenis Penelitian

Dalam penelitian ini, penulis menggunakan jenis penelitian deskriptif komparatif, yaitu membandingkan teori PSAK No. 30 (Revisi 2011) dengan praktek akuntansi leasing yang dilakukan pada. PT. Federal Internasional Finance (FIF) Cabang Manado.

Jenis Data berikut :

Pada umumnya dalam penelitian ini ada dua jenis data yang digunakan yaitu sebagai

1. Data kualitatif merupakan paradigma penelitian yang menekankan ada pemahaman mengenai masalah-masalah dalam kehidupan sosial berdasarkan kondisi realitas (natural setting) yang holistis, komplek dan rinci (Sidik, Saludin 2009:118). Dalam penelitian ini, data kualitatif adalah data yang disajikan deskriptif atau berbentuk uraian berupa sejarah dan struktur organisasi $P T$. Federal Internasional Finance (FIF) Cabang Manado,

2. Data kuantitatif bersifat dapat diukur dalam suatu skala numerik (Sugiyono 2010:106). Dalam penelitian ini, data kuantitatif berupa data akuntansi leasing pada PT. Federal Internasional Finance (FIF) Cabang Manado.

\section{Tempat dan Waktu Penelitian}

Penelitian ini mengambil data penelitian di PT. Federal Internasional Finance (FIF) Cabang Manado, yang beralamat di Jln. Sam Ratulangi No. 9 Manado. Waktu penelitian dimulai dari bulan Agustus tahun 2015 sampai dengan bulan Februari tahun 2016.

\section{Prosedur Penelitian}

Langkah-langkah dalam pengumpulan data adalah sebagai berikut.

1. Melakukan permohonan izin penelitian pada PT. Federal Internasional Finance Cabang Manado

2. Melakukan wawancara dengan pihak perusahaan yaitu kepala bagian kredit $P T$. Federal Internasional Finance Cabang Manado

3. Mengumpulkan data yang diperlukan

4. Melakukan proses olah data dan analisis data mengenai akuntansi leasing

5. Membuat hasil dan pembahasan penelitian

6. Membuat kesimpulan dan saran untuk perusahaan 
7. Memberikan hasil penelitian kepada perusahaan

\section{Metode Analisis}

Metode yang digunakan dalam menganalisis data yang diperoleh adalah metode deskriptif yaitu untuk mengumpulkan, menyusun, menganalisis data, memperoleh gambaran sebenarnya. Metode ini akan menganalis data akuntansi leasing oleh PT. Federal Internasional Finance (FIF) Cabang Manado untuk kemudian dibandingkan dengan teori yang ada sehingga mampu memberikan informasi yang lengkap bagi pemecahan masalah yang dihadapi hingga akhirnya penarikan kesimpulan.

\section{HASIL PENELITIAN DAN PEMBAHASAN Gambaran Umum Perusahaan}

PT. Federal Internasional Finance (FIF) didirikan dengan nama Mitrapusaka Artha Finance pada tanggal 1 Mei 1989 kemudian berganti nama menjadi Federal Internasional Finance (FIF) pada tahun 1991. Berdasarkan ijin usaha yang diperolehnya, maka Perseroan bergerak dalam bidang sewa guna usaha, anjak piutang dan pembiayaan konsumen.

Visi : Memastikan PT. Federal Internasional Finance (FIF) menjadi perusahaan yang dikagumi serta memberikan nilai tambah bagi masyrakat dan lingkungan sekitar.

Misi: 1. Meningkatkan kualitas hidup masyarakat di sekitar lingkungan kantor.

2. Membangun hubungan yang harmonis dengan komunitas sekitar lingkungan kantor.

\section{Hasil Penelitian}

3. Menciptakan image perusahaan yang positif bagi masyarakat.

4. Menciptakan lingkungan kerja yang nyaman, aman, dan sehat bagi karyawan.

\section{Proses Terjadinya Piutang}

Setelah adanya kesepakatan antara pihak perusahaan dengan pihak pembeli, yang dimana sebelumnya sudah diadakan survey terhadap calon konsumen yang dilakukan oleh surveyor dan sudah di autorisasi oleh Credit Head maka selanjutnya perusahaan dan calon konsumen menandatangani surat perjanjian kontrak. Piutang dianggap sudah terjadi.

\section{Pengakuan dan Pencatatan Piutang}

Dalam pengakuan dan pencatatan PT. Federal International Finance (FIF) Cabang Manado menggunakan model akuntansi leasing capital lease lebih tepatnya model pembiayaan langsung. Dalam hal ini penerapan akuntansi piutang oleh PT. FIF Cabang Manado telah disesuaikan dengan PSAK No. 30 tahun 2011 tentang sewa. Contoh pada tanggal 27 September 2015 PT. FIF melakukan transaksi direct finance lease atas aktiva (kendaraan bermotor) dengan harga on the road (OTR) Rp.22.950.000, 3,10\% dari harga OTR selama 2 tahun, margin $9,50 \%$ dari OTR selama 2 tahun.

Perhitungan :

OTR

Asuransi 3,10\% x 2

Harga Beli

DP Murni $10 \%$

Harga Perolehan

Margin 9,50\% x 2

Pembiayaan
Rp. $22.950 . .000$

Rp. 1.422 .900

(Rp. 2.295.000) -

Rp. 22.077.900

$\frac{\text { Rp. } 4.360 .500+}{\text { Rp. } 26.438 .400}+$ 
Contoh transaksi untuk mencatat lease :

Piutang lease

Rp. 26.438.400

Aktiva

Rp. 22.077 .900

Pendapatan bunga diterima dimuka

Rp. 4.369 .500

\section{Penerimaan Piutang}

Penagihan piutang pada PT. FIF cabang Manado dilakukan dengan cara melakukan konfirmasi melalui surat, telepon langsung kepada konsumen untuk memperoleh data yang pasti mengenai pembayaran. Sistem pembayaran yang digunakan untuk pembayaran yaitu pelanggan membayar langsung ke kasir perusahaan yang kemudian oleh kasir disetor ke rekening perusahaan ataupun dapat melalaui ATM, Indomart dan juga Alfamart terdekat.

Contoh transaksi pada saat pembayaran angsuran per bulan :

Kas

Rp. $919.912,5$

Piutang lease

Rp. $919.912,5$

Contoh transaksi untuk mengakui bunga yang diperoleh per bulan :

Pendapatan bunga diterima dimuka

Rp. 181.687,5

Pendapatan bunga

Rp. $181.687,5$

\section{Pembahasan}

Tabel 2. Perbandingan Pengakuan atas Akuntansi Leasing berdasarkan PSAK 30 (Revisi 2011) dengan PT. FIF Manado

\begin{tabular}{|c|c|c|}
\hline $\begin{array}{c}\text { Berdasarkan } \\
\text { PSAK 30 (Revisi 2011) }\end{array}$ & $\begin{array}{c}\text { Berdasarkan } \\
\text { PT. FIF }\end{array}$ & Kesimpulan \\
\hline $\begin{array}{l}\text { 1. Mengakui sewa pembiayaan } \\
\text { sebagai aset dan liabilitas dalam } \\
\text { laporan posisi keuangan sebesar } \\
\text { nilai wajar aset sewaan atau } \\
\text { sebesar nilai kini dari } \\
\text { pembayaran sewa minimum. }\end{array}$ & $\begin{array}{l}\text { Sewa pembiayaan diakui } \\
\text { sebesar nilai wajar, dikurangi } \\
\text { dengan biaya-biaya transaksi } \\
\text { yang terjadi. }\end{array}$ & Sesuai \\
\hline $\begin{array}{l}\text { 2. Tingkat diskonto yang } \\
\text { digunakan dalam perhitungan } \\
\text { nilai kini dari pembayaran sewa } \\
\text { minimum adalah tingkat suku } \\
\text { bunga implisit dalam sewa. }\end{array}$ & $\begin{array}{l}\text { Menggunakan tingkat suku } \\
\text { bunga implisit dalam } \\
\text { perhitungan pembayaran sewa } \\
\text { minimum. }\end{array}$ & Sesuai \\
\hline $\begin{array}{l}\text { 3. Biaya langsung awal yang } \\
\text { dikeluarkan lessee ditambahkan } \\
\text { ke dalam jumlah yang diakui } \\
\text { sebagai aset. }\end{array}$ & $\begin{array}{l}\text { Aset diakui sudah termasuk } \\
\text { biaya langsung awal yang } \\
\text { dikeluarkan oleh lessee. }\end{array}$ & Sesuai. \\
\hline $\begin{array}{l}\text { 4. Transaksi dan kejadian lainnya } \\
\text { dicatat dan disajikan sesuai } \\
\text { dengan substansi dan realitas } \\
\text { keuangannya, dan tidak selalu } \\
\text { mengikuti bentuk legalnya }\end{array}$ & $\begin{array}{lr}\text { Pencatatan transaksi dan } \\
\text { penyajian kejadian lainnya } \\
\text { disesuaikan dengan realitas } \\
\text { keuangannya. }\end{array}$ & Sesuai. \\
\hline
\end{tabular}

Sumber : Data Olahan 2016 
Tabel 3. Perbandingan Pengukuran atas Akuntansi Leasing berdasarkan PSAK 30 (Revisi 2011) dengan PT. FIF Manado

\begin{tabular}{|c|c|c|}
\hline $\begin{array}{c}\text { Berdasarkan } \\
\text { PSAK } 30 \text { (Revisi 2011) }\end{array}$ & $\begin{array}{l}\text { Berdasarkan } \\
\text { PT. FIF }\end{array}$ & Kesimpulan \\
\hline 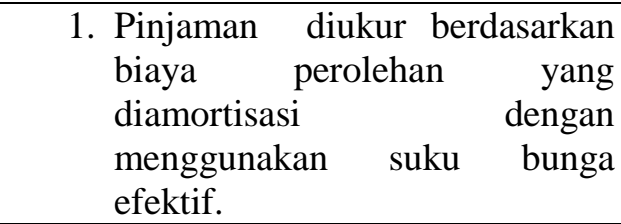 & $\begin{array}{l}\text { Pinjaman diukur pada biaya } \\
\text { perolehan diamortisasi dengan } \\
\text { menggunakan metode suku } \\
\text { bunga efektif. }\end{array}$ & Sesuai \\
\hline $\begin{array}{l}\text { 2. Estimasi pengukuran dengan } \\
\text { alokasi beban keuangan ke } \\
\text { setiap periode. }\end{array}$ & $\begin{array}{l}\text { Mengalokasikan } \\
\text { keuangan ke setiap periode } \\
\text { selama masa sewa dengan } \\
\text { menggunakan beberapa bentuk } \\
\text { aproksimasi r untuk } \\
\text { memudahkan perhitungan. }\end{array}$ & Sesuai \\
\hline $\begin{array}{l}\text { 3. Model akuntansi leasing: capital } \\
\text { lease dan operating lease. }\end{array}$ & $\begin{array}{l}\text { Menggunakan model capital } \\
\text { lease dengan metode direct } \\
\text { finance lease. }\end{array}$ & Sesuai. \\
\hline
\end{tabular}

Sumber : Data Olahan 2016

Tabel 4.Perbandingan Pengungkapan atas Akuntansi Leasing berdasarkan PSAK 30 (Revisi 2011) dengan PT. FIF Cabang Manado

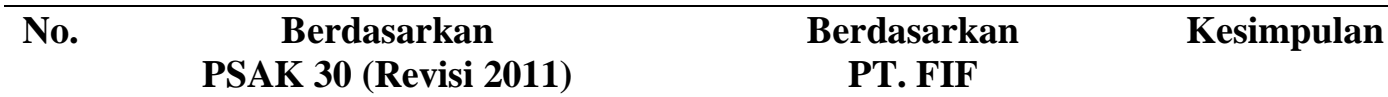

\begin{tabular}{|c|c|c|c|}
\hline & $\begin{array}{l}\text { 1. Piutang disajikan dalam laporan } \\
\text { posisi keuangan sebesar nilai } \\
\text { dikurangi cadangan kerugian } \\
\text { piutang. }\end{array}$ & $\begin{array}{l}\text { Nilai piutang yang disajikan } \\
\text { dalam laporan keuangan } \\
\text { adalah nilai setelah dikurangi } \\
\text { dengan cadangan kerugian } \\
\text { piutang. }\end{array}$ & Sesuai \\
\hline 2. & $\begin{array}{l}\text { Rekonsiliasi antara total } \\
\text { pembayaran sewa minimum di } \\
\text { masa depan pada tanggal } \\
\text { pelaporan, dengan nilai kininya. } \\
\text { Catatan atas laporan keuangan } \\
\text { menjelaskan } \\
\text { akuntansi, rincian pebijakan } \\
\text { menurut jenis, rekonsiliasi } \\
\text { cadangan piutang, dan informasi } \\
\text { khusus terkait piutang seperti }\end{array}$ & $\begin{array}{l}\text { Penyajian ikhtisar kebijakan } \\
\text { akuntansi, asset keuangan } \\
\text { diukur pada nilai wajar serta } \\
\text { penjelasan pinjaman yang } \\
\text { diberikan dan klasifikasi } \\
\text { cadangan kerugian piutang } \\
\text { dan melakukan akumulasi } \\
\text { penyisihan piutang tidak } \\
\text { tertagih atas pembayaran sewa } \\
\text { minimum. }\end{array}$ & Sesuai. \\
\hline
\end{tabular}


piutang dijaminkan dan

penjelasan rinci debitur tertentu

dukur nilai wajar.

Sumber : Data Olahan 2016

\section{KESIMPULAN}

Berdasarkan hasil penelitian dan pembahasan, maka penulis mengemukakan kesimpulan sebagai berikut:

Dalam penerapan PSAK 30 (Revisi 2011) atas akuntansi leasing oleh PT. Federal International Finance Cabang Manado (FIF) telah sesuai dengan standar yang berlaku. PT. FIF menggunakan model akuntansi leasing capital lease, dapat diketahui dari ketentuan dalam surat lease pada perusahaan tersebut, yang menyatakan adanya hak opsi bagi pihak lease pada saat berakhirnya masa lease, dimana ketentuan ini tergolong dalam satu kriteria yang ada pada capital lease. Dalam capital lease dimasa akhir pembayaran sewa, hak opsi kepemilikan kendaraan bagi lease. PT. FIF menggunakan model akuntansi leasing capital lease dengan model direct financing lease atau metode pembiayaan langsung.. Dalam pengakuan, pengukuran, dan pengungkapan sewa pembiayaan PT. FIF telah sesuai dengan standar akuntansi yang berlaku karena sewa pembiayaan diakui sebesar nilai wajar, dikurangi dengan biaya-biaya transaksi yang terjadi.

Penulis mengemukakan saran-saran sebagai berikut:

1. Diharapkan dipertahankan dan diterapkan secara konsisten disetiap periode akuntansi agar menghasilkan laporan keuangan yang lebih akurat dalam mencerminkan posisi keuangan, prinsip transparansi dan hasil operasi perusahaan.

2. Dalam pencatatan dan pelaporan piutang, sebaiknya perusahaan menetapkan kebijakan untuk adanya pemisahan pencatatan piutang di cabang dan yang ada di pusat. Ini dapat membantu perusahaan mengetahui dengan jelas mengenail kekuatan dana perusahaan.

\section{DAFTAR PUSTAKA}

Alsayeh, 2009. Leasing in Jordan, the Current Reality and Future. Journal of Jordanian.

Ang \& Pamela P. Peterson, 2012. The Leasing Puzzle. The Journal of Finance Vol 39, Issue $\underline{4}$.

Bashi, Fatbardha Molla, 2013. The Future of Leasing Accounting. Journal of Applied Economics and Business.

Bragg. 2012. IFRS Made Easy. Indeks.Jakarta

Callimaci, Anne Fortin, Suzanne Landry, 2010. Determinants of Leasing Propensity in Canadian Listed Companies. International Journal of Managerial Finance ISSN: 1743-9132.

Chu, Robert Mathieu, Ping Zhang, 2008. Why Firms Lease Short-Lived Assets: A Tax-Based Explanation. Canadian tax journal. Vol. 56, No 3, 639-60.

Dhaliwal, J. Scott Judd, Matthew Serfling \& Sarah Shaikh, 2016. Customer Concentration Risk and The Cost of Equity Capital. Journal of Accounting and Economics, vol. 61, issue 1, pages 23-48.

Durocher \& Anne Fortin, 2010. Proposed Changes in Lease Accounting and Private Business Bankers' Credit Decisions. Accounting Perspectives. 
Erickson \& Ruben Trevino, 2010. A Pecking Order Approach to Leasing. Journal Of Financial And Strategic Decisions. Vol. 7 No. 3.

Ikatan Akuntan Indonesia., 2012. Standar Akuntansi Keuangan. Salemba Empat, Jakarta.

Izati, 2014. Analisis Akuntansi Sewa Berdasarkan PSAK No.30 Pada MAF MCF Tanjung

Pinang. Universitas Maritim Raja Ali Haji.

Kieso, Donald E., Jerry J Weygandt, and Terry D. Warfield, 2008. Intermediate Accounting, 12th edition,: John Wiley \& Sons,United States of America.

Kombaitan. 2013. Penerapan PSAK No. 30 Tentang Perlakuan Akuntansi Sewa Aktiva Tetap Pada PD. Bangun Bitung. Jurnal EMBA Vol 1, No. 3, Hal.11-21.

Lee, 2008. Capital Operating Leases A Research Report. Federal Accounting Standards Advisory Board.

Lee, Daniel Gyung Paik, Sung Wook Yoon, 2014. The Effect of Capitalizing Operating Leases on the Immediacy to Debt Covenant Violations. Journal of Accounting and Finance vol. 14.

Mackenzie \& G Hart, 2010. Finance Lease Taxation: Giving Tax Losses to Lenders. Journal of Law and Financial Managment 30.

Martani, Sylvia Veronica NPS, Ratna Wardhani, Aria Farahmita, Edward Tanujaya, 2012. Akuntansi Keuangan Menengah. Berbasis PSAK. Penerbit Salemba Empat. Jakarta.

Orabi, 2014. The Impact of Leasing Decisions on the Financial Performance of Industrial Companies. Global Journal of Management and Business Research. Vol 14 Issue 2 Version 1.

PPAK Fakultas Ekonomi \& Bisnis, 2015. Panduan Penulisan Laporan Akhir. Universitas Sam Ratulangi, Manado.

Prihadi, 2011. Praktis Memahami Laporan Keuangan sesuai IFRS \& PSAK. Cetakan I. Penerbit PPM.

Runtuwene, 2013. Penerapan Akuntansi Piutang Leasing Untuk Perencanaan Dan Pengendalian Pada PT. Suzuki Finance Indonesia Cabang Manado. Jurnal EMBA, Vol. 1 No. 4: 998-1006.

Santoso, 2010. Akuntansi Keuangan Menengah. Penerbit PT. Refika Aditama. Bandung.

Sparta, Safitri, 2010. Analisis Penerapan PSAK No 30 Tentang Sewa Guna Usaha. Jurnal Akuntansi Vol 5, Tahun XIV/01. Hal. 88-97.

Sugiyono, 2010. Metode Penelitian Bisnis (Pendekatan Kuantitatif, Kualitatif, dan R\&D. Alfabeta. Bandung.

Supardi, 2013.Aplikasi Statistika dalam Penelitian. Smart. Jakarta

Tai, 2013. Constructive Capitalization of Operating Leases in the Hong Kong Fast-Food Industry International. Journal of Accounting and Financial Reporting ISSN 21623082 2013, Vol. 3, No. 1.

Wong, 2010. International Lease Accounting and Tax Consequences: The Hong Kong Perspective. International Journal of Economics and Finance Vol. 2, No. 4.

Wong, 2015. The Impact of Lease Capitalisation on Financial Statements and Key Ratios. Accounting Business and Finance Journal and Authors.

Yanti, Arifulsyah Hamdani, 2013. Analisis Akuntansi Leasing Pada PT. Puri Green Resources Pekanbaru. Jurnal Akuntansi Keuangan dan Bisnis Vol.6. 